\title{
Synthesis and characterization of mesoporous magnetic
}

\section{nanocomposites wrapped with chitosan gatekeepers for $\mathrm{pH}$-sensitive controlled release of doxorubicin}

\author{
Juan Wu, Wei Jiang, Yewen Shen, Wei Jiang", Renbing Tian \\ National Special Superfine Powder Engineering Research Center, Nanjing University of Science and \\ Technology, Nanjing 210094, China
}

\begin{abstract}
Multifunctional nanocarriers based on the $\mathrm{Fe}_{3} \mathrm{O}_{4}$ nanoparticles core and mesoporous silica shell $\left(\mathrm{mSiO}_{2}\right)$ were synthesized for controlled drug release through magnetic targeting and $\mathrm{pH}$-sensitive performances. The developed $\mathrm{Fe}_{3} \mathrm{O}_{4} @ \mathrm{mSiO}_{2}$ nanocarriers exhibited a suitable size $(63 \mathrm{~nm})$ and good magnetic responsibility, doxorubicin (DOX) could be successfully loaded into the mesoporous of $\mathrm{Fe}_{3} \mathrm{O}_{4} @ \mathrm{mSiO}_{2}$ via electrostatic interaction, and the drug loading content and loading efficiency are $29.3 \%$ and $93.6 \%$, respectively. The chitosan (CS) was employed to wrap the $\mathrm{Fe}_{3} \mathrm{O}_{4} @ \mathrm{mSiO}_{2}-\mathrm{DOX}$ as the blocking agent to inhibit premature drug release, and the final $\mathrm{CS} / \mathrm{Fe}_{3} \mathrm{O}_{4} @ \mathrm{mSiO}_{2}-\mathrm{DOX}$ exhibited excellent $\mathrm{pH}$-sensitivity, $86.1 \% \mathrm{DOX}$ was released within $48 \mathrm{~h}$ at $\mathrm{pH}$ 4.0. Furthermore, all the release behaviors fit the Higuchi model very well and a purely diffusion-controlled process played a major role on DOX release from $\mathrm{CS} / \mathrm{Fe}_{3} \mathrm{O}_{4} @ \mathrm{mSiO}_{2}$-DOX. In addition, MTT assays in human liver hepatocellular carcinoma cells (HepG2) demonstrated that the $\mathrm{CS} / \mathrm{Fe}_{3} \mathrm{O}_{4} @ \mathrm{mSiO}_{2}-\mathrm{DOX}$ had high anti-tumor activity, while the $\mathrm{Fe}_{3} \mathrm{O}_{4} @ \mathrm{mSiO}_{2}$ nanocarriers were practically non-toxic. Thus, our results revealed that the $\mathrm{CS} / \mathrm{Fe}_{3} \mathrm{O}_{4} @ \mathrm{mSiO}_{2}$-DOX could play an important role in the development of intracellular delivery
\end{abstract}

\footnotetext{
${ }^{*}$ Corresponding author. Tel.: +86-25-84315042; Fax.: +86-25-84315042

E-mail address: superfine_jw@126.com (W. Jiang)
} 
nanodevices for cancer therapy.

Keywords: $\mathrm{Fe}_{3} \mathrm{O}_{4}$; mesoporous silica; chitosan; doxorubicin; $\mathrm{pH}$-sensitive; targeted cancer therapy

\section{Introduction}

Nanotechnology provides a flexible platform for the development of new nanomaterials that with distinct characteristics and functionalities suitable for applications in specific areas [1-4]. Of the nanomaterials studies, the magnetic nanomaterials especially the $\mathrm{Fe}_{3} \mathrm{O}_{4}$ nanoparticles have been widely studied in the past decades because of their high potential applications in many areas especially in biomedical researches [5-10], due to their inherently ultra-fine size, low toxicity, biocompatibility and adequate magnetic properties [11]. These properties are fully exploited when they are used for drug delivery. However, due to high magnetic interaction and high surface area, the $\mathrm{Fe}_{3} \mathrm{O}_{4}$ nanoparticles get agglomerated easily in the absence of any surface coating, and the bared $\mathrm{Fe}_{3} \mathrm{O}_{4}$ nanoparticles also can be easily oxidized in biological media [12-14]. It is therefore necessary to modify the surface of bared $\mathrm{Fe}_{3} \mathrm{O}_{4}$ nanoparticles or coat them properly by another biocompatible material so as to functionalize the nanoparticles and avoid those disadvantages $[15,16]$.

Frequently, silica has been widely used as surface modifying agent for $\mathrm{Fe}_{3} \mathrm{O}_{4}$ nanoparticles, because of its flexible and robust properties, including easy modification, excellent chemical stability and outstanding biocompatibility in human body [17-20]. Mesoporous silica $\left(\mathrm{mSiO}_{2}\right)$, particularly, has been utilized as surface modifying agent while as vehicle for the delivery of special drugs due to its nontoxic nature, high pore volume and large surface area (high drug loading capacity) [21-23]. However, pure $\mathrm{mSiO}_{2}$ always face some practical applicability limitations due to the premature or burst drug release within several hours. Thence, it is necessary to functionalize such mesostructures in a special way to break these limitations [24]. 
Presently, the interesting concept of stimulus-responsive gatekeeping has been introduced to optimize the application of $\mathrm{mSiO}_{2}$ in drug delivery. And nanoparticles, organic molecules and supramolecular nanovalves have been employed as "gatekeepers" for $\mathrm{mSiO}_{2}$ to show its well-controlled drug release performance $[25,26]$. The controlled drug release process can be regulated either by external stimuli such as thermal and light, or by internal stimuli such as enzymes and $\mathrm{pH}$ [27-30]. Prominently, chitosan (CS), one of the high performance biomass materials, has been widely used in intelligent drug delivery system due to its unique properties like non-toxicity, biocompatibility, biodegradability and so on [31,32]. In addition, unlike any other polymers coating, most of which need to add poisonous solvent and the preparation processes are complex. Using CS to coat the $\mathrm{mSiO}_{2}$ does not need those poisonous solvent and its preparation process of hydrogen bonding is very simple and facile. Moreover, the ionization of great amount of amino groups on chains of CS provides it as a pH-sensitive “gatekeeper”.

Doxorubicin (DOX) is one of the most widely used chemotherapeutic drugs for tumor therapeutics. However, standard chemotherapy involves the use of a relatively high dose of drugs in order to efficiently kill cancer cells due to the lack of ability to target cancer cells, which is inevitably associated with numerous negative side effects such as cardiotoxicity and intrinsic or acquired drug resistance of tumors [33-35]. Therefore, to develop a novel DOX delivery system is a potential method to inhibit tumor growth while avoiding or minimizing these side effects.

With all of these considerations in mind, we synthesized the mesoporous magnetic nanocomposites $\left(\mathrm{Fe}_{3} \mathrm{O}_{4} @ \mathrm{mSiO}_{2}\right)$ as drug carriers consisting of a magnetic $\mathrm{Fe}_{3} \mathrm{O}_{4}$ nanoparticles core and $\mathrm{mSiO}_{2}$ shell, and the final drug delivery system $\left(\mathrm{CS} / \mathrm{Fe}_{3} \mathrm{O}_{4} @ \mathrm{mSiO}_{2}-\mathrm{DOX}\right)$ showed a magnetic targeting property $\left(\mathrm{Fe}_{3} \mathrm{O}_{4}\right)$ associated with $\mathrm{pH}$-sensitive (CS) controlled release. As shown in Fig. 1, in 
the first step, the core-shell $\mathrm{Fe}_{3} \mathrm{O}_{4} @ \mathrm{mSiO}_{2}$ nanomaterials were prepared as the drug carriers. Then the DOX molecules were loaded into the mesoporous of $\mathrm{Fe}_{3} \mathrm{O}_{4} @ \mathrm{mSiO}_{2}$ via electrostatic interaction. After the drug loading, the CS was employed to wrap the $\mathrm{Fe}_{3} \mathrm{O}_{4} @ \mathrm{mSiO}_{2}-\mathrm{DOX}$ as the blocking agent to inhibit premature drug release. It is known that the acidic environment in tumor tissues promotes the degradation of CS, thereby allowing the release of DOX.

\section{Materials and methods}

\subsection{Materials}

All the chemical agents were used as-received without further purification. Ferric chloride $\left(\mathrm{FeCl}_{3} \cdot 6 \mathrm{H}_{2} \mathrm{O}\right)$, ferrous sulfate $\left(\mathrm{FeSO}_{4} \cdot 7 \mathrm{H}_{2} \mathrm{O}\right)$, dulbecco's modified eagle medium (DMEM), fetal bovine serum (FBS) and 3-[4,5-dimethylthialzol-2-yl]-2,5-diphenyltetrazolium bromide (MTT) were purchased from Sigma-Aldrich. Ammonia $\left(\mathrm{NH}_{3} \cdot \mathrm{H}_{2} \mathrm{O}, 25 \mathrm{wt} \%\right)$, oleic acid (OA), n-octane, ethylene glycol (EG), cetyltrimethyl ammonium bromide (CTAB) and acetic acid (98\%) were supplied by

Sinopharm Chemical Reagent Co., Ltd., Shanghai, China. Tetraethyl orthosilicate (TEOS), 1,3,5-trimethylbenzene, chitosan (CS), acridine orange base (AO) and ethidium bromide (EB) were purchased from Aladdin. The human liver hepatocellular carcinoma cells (HepG2) were supplied by Chinese Academy of Sciences Cell Bank, Shanghai, China.

\subsection{Preparation of $\mathrm{Fe}_{3} \mathrm{O}_{4}$ ferrofluid}

The $\mathrm{Fe}_{3} \mathrm{O}_{4}$ nanoparticles were prepared by a co-precipitation method with some modification [36]. Briefly, $12.2 \mathrm{~g} \mathrm{FeCl}_{3} \cdot 6 \mathrm{H}_{2} \mathrm{O}$ and $8.4 \mathrm{~g} \mathrm{FeSO}_{4} \cdot 7 \mathrm{H}_{2} \mathrm{O}$ were dissolved in $25 \mathrm{~mL}$ of distilled water, stirred and heated to $70^{\circ} \mathrm{C}$ under the protection of $\mathrm{N}_{2}$. Then, $15 \mathrm{~mL} \mathrm{NH}_{3} \cdot \mathrm{H}_{2} \mathrm{O}$ (25 wt.\%) was injected into the mixture rapidly and the $\mathrm{pH}$ of the reaction system was adjusted to 9-10. After reaction for $30 \mathrm{~min}, 2.5 \mathrm{~g}$ OA was added and the reaction temperature was raised to $85^{\circ} \mathrm{C}$ and maintained at this temperature for 
20min, followed by cooling the product to room temperature. Finally, the products were washed with distilled water several times and dispersed in n-octane to form a $\mathrm{Fe}_{3} \mathrm{O}_{4}$ ferrofluid.

\subsection{Synthesis of $\mathrm{Fe}_{3} \mathrm{O}_{4} @ \mathrm{mSiO}_{2}$ magnetic nanocomposites}

The synthetic process of $\mathrm{Fe}_{3} \mathrm{O}_{4} @ \mathrm{mSiO}_{2}$ magnetic nanocomposites was similar to the previous report [37]. Firstly, $0.74 \mathrm{~mL}$ of $\mathrm{Fe}_{3} \mathrm{O}_{4}$ ferrofluid (2.5\% W/V) was added into $10 \mathrm{~mL}$ of aqueous solution containing $0.15 \mathrm{~g} \mathrm{CTAB}$ under ultrasound of $30 \mathrm{~min}$ at $50^{\circ} \mathrm{C}$. Then, the mixture was stirred at $70^{\circ} \mathrm{C}$ for $15 \mathrm{~min}$. At the same time, a solution contained $30 \mathrm{~mL}$ of water, $10 \mathrm{~mL} \mathrm{EG}$ and $0.7 \mathrm{~mL} \mathrm{N \textrm {N } _ { 3 }} \cdot \mathrm{H}_{2} \mathrm{O}$ was prepared. After stirring, the solution was added into the mixture and continued stirring for $10 \mathrm{~min}$. Afterward, $0.2 \mathrm{~g}$ of 1,3,5-trimethylbenzene which acted as swelling agent was added at this temperature. After the reaction for $2 \mathrm{~h}, 400 \mu \mathrm{L}$ TEOS was dropwise added to the reaction solution. The solution was stirred at $70^{\circ} \mathrm{C}$ for $3 \mathrm{~h}$ and then cooled to room temperature. The final $\mathrm{Fe}_{3} \mathrm{O}_{4} @ \mathrm{mSiO}_{2}$ magnetic nanocomposites were collected by magnet and washed with water several times, then dried under vacuum at $35^{\circ} \mathrm{C}$.

\subsection{Drug loading $\left(\mathrm{Fe}_{3} \mathrm{O}_{4} @ \mathrm{mSiO}_{2}-\mathrm{DOX}\right)$ and chitosan wrapping $\left(\mathrm{CS} / \mathrm{Fe}_{3} \mathrm{O}_{4} @ \mathrm{mSiO}_{2}-\mathrm{DOX}\right)$}

$15 \mathrm{mg}$ dry $\mathrm{Fe}_{3} \mathrm{O}_{4} @ \mathrm{mSiO}_{2}$ magnetic nanocomposites were dispersed in $10 \mathrm{~mL}$ of water under ultrasound, then $5 \mathrm{mg}$ DOX was added and the mixture was stirred in the dark at room temperature for 48 h. Finally, the $\mathrm{Fe}_{3} \mathrm{O}_{4} @ \mathrm{mSiO}_{2}$-DOX were collected by magnet and washed twice with water. Meanwhile, $0.5 \mathrm{~g} \mathrm{CS}$ was dissolved in $20 \mathrm{~mL}$ of acetic acid aqueous solution (10\% V/V) under stirring and ultrasound for $15 \mathrm{~min}$ and the $\mathrm{pH}$ was adjusted to 6.0 with saturated $\mathrm{NaOH}$ solution. Then the freshly prepared $\mathrm{Fe}_{3} \mathrm{O}_{4} @ \mathrm{mSiO}_{2}$-DOX was added under ultrasound for 10 min and the reaction went on for $40 \mathrm{~h}$ at room temperature. The $\mathrm{CS} / \mathrm{Fe}_{3} \mathrm{O}_{4} @ \mathrm{mSiO}_{2}-\mathrm{DOX}$ was obtained by centrifugation, washed with water twice and dried under vacuum at room temperature. The loading content (\%) and loading 
efficiency (\%) of DOX were determined by the UV-vis spectroscope at $482 \mathrm{~nm}$ and calculated by the following equations.

$$
\begin{aligned}
& \text { Loading content }=\frac{\text { the amount of } \mathrm{DOX} \text { in } \mathrm{CS} / \mathrm{Fe}_{3} \mathrm{O}_{4} @ \mathrm{mSiO}-\mathrm{DOX}}{\text { the amount of } \mathrm{CS} / \mathrm{Fe}_{3} \mathrm{O}_{4} @ \mathrm{mSiO}_{2}} \times 100 \% \\
& \text { Loading efficiency }=\frac{\text { the amount of } \mathrm{DOX} \text { in } \mathrm{CS} / \mathrm{Fe}_{3} \mathrm{O}_{4} @ \mathrm{mSiO} \mathrm{O}_{2}-\mathrm{DOX}}{\text { the amount of } \mathrm{DOX} \text { feeding }} \times 100 \%
\end{aligned}
$$

\subsection{Characterizations}

The morphology of the samples was observed by transmission electron microscopy (TEM, Model Tecnai 12, Philips Co. Ltd., Holland) and field-emission scanning electron microscopy (FE-SEM, Hitachi S-4800, Hitachi, Japan). The average particle size and distribution were evaluated by measuring the largest internal dimension of 200 particles and show the histogram and the fitting Gaussian curves used to extract the average particle sizes and standard deviations. The hydrodynamic dynamic diameters were determined by dynamic light scattering (DLS, BI-90Plus, Brookhaven Co. Ltd., USA). Surface charge was evaluated by the zeta potential analyzer (BI-90Plus, Brookhaven Co. Ltd., USA). The surface area was calculated according to the conventional Brunauer-Emmett-Teller (BET) method and the adsorption branches of the isotherms were used for the calculation of the pore parameters using the $\mathrm{BJH}$ method using the Quantachrome Autosorb 1 software (Quantachrome Instruments, USA). The crystalline phases were carried out by powder X-ray diffraction (XRD) performed on a Bruker D8 (Bruker Co. Ltd., Germany) advance system using $\mathrm{Cu} \mathrm{K} \alpha$ radiation $(\lambda=1.5418 \AA)$. The thermal stability of the dry samples were measured by thermogravimetric analysis (TG, Model TA2100, TA Instruments, USA) under $\mathrm{N}_{2}$ at a heating rate of $10^{\circ} \mathrm{C} / \mathrm{min}$. Fourier-transform infrared spectroscopy (FT-IR) spectra were recorded on Vector 22 spectrometer (Bruker Co. Ltd., Germany) using the $\mathrm{KBr}$ pellet technique. The UV-vis absorbance spectra were recorded by UV-vis spectrophotometry (Agilent Co. Ltd., USA). Magnetic properties of the particles were detected at room 
temperature using vibrating sample magnetometer (VSM, Model 7410, Lake Shore Co. Ltd., USA).

\subsection{In vitro release of $D O X$}

The experiment of in vitro release of DOX was conducted like previously reported [6,33]. First, $\mathrm{Fe}_{3} \mathrm{O}_{4} @ \mathrm{mSiO}_{2}-\mathrm{DOX}$ and $\mathrm{CS} / \mathrm{Fe}_{3} \mathrm{O}_{4} @ \mathrm{mSiO}_{2}-\mathrm{DOX}$ were dispersed in PBS buffer solutions ( $\mathrm{pH}$ 4.0, 5.8 and 7.5) at concentration of $2 \mathrm{mg} / \mathrm{mL}$, and then sealed in a dialysis bag which was submerged in $6 \mathrm{~mL}$ of media solution, and finally kept in the oscillator at $37^{\circ} \mathrm{C}$. At selected time intervals, $3 \mathrm{~mL}$ PBS outside the dialysis bag was removed for UV-vis analysis at $482 \mathrm{~nm}$ and replaced by the fresh with the same volume which was preheated to $37^{\circ} \mathrm{C}$. The release experiments were conducted in triplicate. The results presented are the average data with standard deviations.

\subsection{Toxicity assays}

The viability of cells in the presence of nanoparticles was investigated using a MTT assay. Firstly, HepG2 cells were grown in a monolayer of DMEM supplemented with $10 \%(\mathrm{v} / \mathrm{v}) \mathrm{FBS}$ in a humidified $5 \% \mathrm{CO}_{2}$ atmosphere at $37{ }^{\circ} \mathrm{C}$. Then the HepG2 cells that in good condition were seeded in 96-well plates $\left(5 \times 10^{3}\right.$ cells/well $)$ in $200 \mu \mathrm{L}$ of the medium and grown overnight. After that, the cells were incubated with various concentrations of $\mathrm{Fe}_{3} \mathrm{O}_{4} @ \mathrm{mSiO}_{2}$, free $\mathrm{DOX}$ and $\mathrm{CS} / \mathrm{Fe}_{3} \mathrm{O}_{4} @ \mathrm{mSiO}-\mathrm{DOX}$ for 24 h. Afterwards, the cells were incubated in a medium containing MTT $(5 \mathrm{mg} / \mathrm{mL})$ for $4 \mathrm{~h}$ and the absorbance at a wavelength of $570 \mathrm{~nm}$ of each well was measured using a multifunctional microplate reader (TECAN Infinite 200 Pro, Austria). The relative cell viability (\%) was calculated using equation as follows:

$$
\text { Relative cell viability }=\frac{\text { absorbance of treated cells }}{\text { absorbance of control cells }} \times 100 \%
$$

Cytotoxicity was expressed as percentage of control cells. The inhibition concentration $50 \%$ ( $\left.\mathrm{IC}_{50}\right)$ is defined as the dose of compound that reaches inhibited cell growth of $50 \%$, was interpolated in the 
growth curves thus obtained. The fluorescence images of HepG2 cells were observed by RFP filter under microscope (Olympus, IX81, Japan).

\section{Results and discussion}

\subsection{Characterization of sample}

Fig. 2 shows the TEM images and particle size distribution diagrams of $\mathrm{Fe}_{3} \mathrm{O}_{4}$ nanoparticles, $\mathrm{Fe}_{3} \mathrm{O}_{4} @ \mathrm{mSiO}_{2}$ nanocomposites and $\mathrm{CS} / \mathrm{Fe}_{3} \mathrm{O}_{4} @ \mathrm{mSiO}_{2}$-DOX. It can be seen from Fig. 2a and b, the as-synthesized $\mathrm{Fe}_{3} \mathrm{O}_{4}$ nanoparticles could be separated from each other very well and the average particle size of $\mathrm{Fe}_{3} \mathrm{O}_{4}$ nanoparticles was about $8 \mathrm{~nm}$. After coating of $\mathrm{mSiO}_{2}$, the $\mathrm{Fe}_{3} \mathrm{O}_{4} @ \mathrm{mSiO}_{2}$ nanocomposites with good dispersibility were spherical and the mesoporous of $\mathrm{mSiO}_{2}$ could be clearly seen (Fig. 2c), in addition the average particle size of $\mathrm{Fe}_{3} \mathrm{O}_{4} @ \mathrm{mSiO}_{2}$ nanocomposites was about $63 \mathrm{~nm}$ (Fig. 2d). While, in Fig. 2e, the mesoporous of $\mathrm{mSiO}_{2}$ could not be clearly seen and the outer layers of $\mathrm{CS} / \mathrm{Fe}_{3} \mathrm{O}_{4} @ \mathrm{mSiO}_{2}-\mathrm{DOX}$ look like a gel, also the $\mathrm{CS} / \mathrm{Fe}_{3} \mathrm{O}_{4} @ \mathrm{mSiO}_{2}-\mathrm{DOX}$ were spherical with a relatively uniform diameter and possessed a smooth surface (Fig. S1). What's more, as can be seen in Fig. 2f, the average particle size of $\mathrm{CS} / \mathrm{Fe}_{3} \mathrm{O}_{4} @ \mathrm{mSiO}_{2}-\mathrm{DOX}$ was about $73 \mathrm{~nm}$, which is a suitable size that both to evade RES of the body as well as penetrate the very small capillaries within the body tissues and therefore may offer the most effective distribution in certain tissues [38]. In addition, the hydrodynamic dynamic diameters of $\mathrm{Fe}_{3} \mathrm{O}_{4} @ \mathrm{mSiO}_{2}$ and $\mathrm{CS} / \mathrm{Fe}_{3} \mathrm{O}_{4} @ \mathrm{mSiO}_{2}-\mathrm{DOX}$ were $125 \mathrm{~nm}$ and $153 \mathrm{~nm}$, respectively (Fig. 3), which evidenced the CS wrapping process. Obviously, both the diameters of $\mathrm{Fe}_{3} \mathrm{O}_{4} @ \mathrm{mSiO}_{2}$ and $\mathrm{CS} / \mathrm{Fe}_{3} \mathrm{O}_{4} @ \mathrm{mSiO}_{2}-\mathrm{DOX}$ obtained by DLS were larger than that determined by TEM, this is because that the size identified by DLS includes the hydrodynamic radius of solvent layers and CS molecules' steric hindrance [6]. The zeta potential of $\mathrm{Fe}_{3} \mathrm{O}_{4} @ \mathrm{mSiO}_{2}$ and $\mathrm{CS} / \mathrm{Fe}_{3} \mathrm{O}_{4} @ \mathrm{mSiO}_{2}$-DOX was measured in deionized water at the concentration of $0.01 \mathrm{mg} / \mathrm{mL}$ (the 
inset table of Fig. 3), $\mathrm{Fe}_{3} \mathrm{O}_{4} @ \mathrm{mSiO}_{2}$ shows a zeta potential of $-14.87 \mathrm{mV}$ derived from the negative charge of surface $\mathrm{Si}-\mathrm{OH}$, which increases to $26.94 \mathrm{mV}$ for $\mathrm{CS} / \mathrm{Fe}_{3} \mathrm{O}_{4} @ \mathrm{mSiO}_{2}-\mathrm{DOX}$ due to the decrease of surface Si-OH substituted by CS and the great amount of amino groups on chains of CS. Based on the above investigation, it is clear that the CS has wrapped the $\mathrm{Fe}_{3} \mathrm{O}_{4} @ \mathrm{mSiO}_{2}-\mathrm{DOX}$ successfully.

The pore structure and related textural properties of $\mathrm{Fe}_{3} \mathrm{O}_{4} @ \mathrm{mSiO}_{2}$ and $\mathrm{CS} / \mathrm{Fe}_{3} \mathrm{O}_{4} @ \mathrm{mSiO}$-DOX were investigated through nitrogen adsorption-desorption measurements. The corresponding adsorption isotherms and the pore size distribution curves are depicted in Fig. 4. In Fig. 4a, both $\mathrm{Fe}_{3} \mathrm{O}_{4} @ \mathrm{mSiO}_{2}$ and $\mathrm{CS} / \mathrm{Fe}_{3} \mathrm{O}_{4} @ \mathrm{mSiO}_{2}$-DOX exhibited type IV adsorption-desorption isotherms and sharp capillary condensation steps covering narrow relative pressure regions, reflecting that uniform mesoporous were present in the samples. Furthermore, H1-type hysteresis loops were obvious of $\mathrm{Fe}_{3} \mathrm{O}_{4} @ \mathrm{mSiO}_{2}$, indicating that the pores of $\mathrm{Fe}_{3} \mathrm{O}_{4} @ \mathrm{mSiO}_{2}$ were open and cylindrical, while $\mathrm{CS} / \mathrm{Fe}_{3} \mathrm{O}_{4} @ \mathrm{mSiO}_{2}-\mathrm{DOX}$ did not shows this, revealing that the DOX had loaded into the pores and the CS had wrapped the $\mathrm{Fe}_{3} \mathrm{O}_{4} @ \mathrm{mSiO}_{2}-\mathrm{DOX}$ successfully. In addition, both $\mathrm{Fe}_{3} \mathrm{O}_{4} @ \mathrm{mSiO}_{2}$ and $\mathrm{CS} / \mathrm{Fe}_{3} \mathrm{O}_{4} @ \mathrm{mSiO}_{2}-\mathrm{DOX}$ had a secondary condensation step at high relative pressure regions (starting from $\mathrm{P} / \mathrm{P}_{0}=0.9$ ), which should be attributed to the interparticle spaces or textual porosity formed among small particles after drying [39]. As can be seen in Fig. 4b, there is a much smaller uptake of $\mathrm{CS} / \mathrm{Fe}_{3} \mathrm{O}_{4} @ \mathrm{mSiO}_{2}-\mathrm{DOX}$ in comparison to its counterpart $\left(\mathrm{Fe}_{3} \mathrm{O}_{4} @ \mathrm{mSiO}_{2}\right)$. Additionally, the surface area and pore volume decreased from $821.5 \mathrm{~m}^{2} / \mathrm{g}$ and $1.997 \mathrm{~cm}^{3} / \mathrm{g}$ of $\mathrm{Fe}_{3} \mathrm{O}_{4} @ \mathrm{mSiO}_{2}$ to $500.1 \mathrm{~m}^{2} / \mathrm{g}$ and $0.762 \mathrm{~cm}^{3} / \mathrm{g}$ of $\mathrm{CS} / \mathrm{Fe}_{3} \mathrm{O}_{4} @ \mathrm{mSiO}_{2}-\mathrm{DOX}$ (the inset table of Fig. 3b). These results are expected due to the DOX drug molecules encapsulated in the pores of $\mathrm{mSiO}_{2}$ and the CS wrapped on the outer surface of $\mathrm{Fe}_{3} \mathrm{O}_{4} @ \mathrm{mSiO}_{2}-\mathrm{DOX}$, confirming that both $\mathrm{Fe}_{3} \mathrm{O}_{4} @ \mathrm{mSiO}_{2}$ and $\mathrm{CS} / \mathrm{Fe}_{3} \mathrm{O}_{4} @ \mathrm{mSiO}_{2}-\mathrm{DOX}$ had been successfully synthesized. 
X-ray diffraction patterns of $\mathrm{Fe}_{3} \mathrm{O}_{4}, \quad \mathrm{Fe}_{3} \mathrm{O}_{4} @ \mathrm{mSiO}_{2}, \quad \mathrm{Fe}_{3} \mathrm{O}_{4} @ \mathrm{mSiO}_{2}-\mathrm{DOX}$ and

$\mathrm{CS} / \mathrm{Fe}_{3} \mathrm{O}_{4} @ \mathrm{mSiO}_{2}$-DOX powders are presented in Fig. 5. As can be seen in Fig. 5a, $\mathrm{Fe}_{3} \mathrm{O}_{4} @ \mathrm{mSiO}_{2}$, $\mathrm{Fe}_{3} \mathrm{O}_{4} @ \mathrm{mSiO}_{2}-\mathrm{DOX}$ and $\mathrm{CS} / \mathrm{Fe}_{3} \mathrm{O}_{4} @ \mathrm{mSiO}_{2}-\mathrm{DOX}$ have a broad characteristic peak at $2 \theta=23.6^{\circ}$, this could be attributed to the intense band of amorphous silica [37]. What's more, four major reflections appear in curve at about $30.0^{\circ}, 35.8^{\circ}, 57.4^{\circ}$ and $63.1^{\circ}$ can be still indexed as the (220), (311), (511) and (440) diffraction peaks of inverse spinel structure for magnetite (JCPDS no. 19-0629) [40], although the characteristic magnetite peaks are much weaker than the amorphous silica. The attenuation of characteristic peaks' intensity and the disappearance of a few peaks of $\mathrm{Fe}_{3} \mathrm{O}_{4}$ may be due to the heavy atom effect of $\mathrm{SiO}_{2}$ indicating the coverage of the $\mathrm{Fe}_{3} \mathrm{O}_{4}$ core by $\mathrm{mSiO}_{2}$. In addition, from the XRD patterns, the particle sizes of $\mathrm{Fe}_{3} \mathrm{O}_{4}, \mathrm{Fe}_{3} \mathrm{O}_{4} @ \mathrm{mSiO}_{2}$ and $\mathrm{CS} / \mathrm{Fe}_{3} \mathrm{O}_{4} @ \mathrm{mSiO}_{2}-\mathrm{DOX}$ were calculated to be $8.6 \mathrm{~nm}, 64.4 \mathrm{~nm}$ and $75.1 \mathrm{~nm}$ by using Scherrer formula, which were similar to those obtained from TEM. In Fig. 5b, the small-angle X-ray diffraction patterns indicate that all the samples reveal only one diffraction peak at about $2 \theta=2.1^{\circ}$, suggesting they all possess the mesoporous structure. Moreover, after drug loading and CS wrapping, the diffraction intensities of $\mathrm{CS} / \mathrm{Fe}_{3} \mathrm{O}_{4} @ \mathrm{mSiO}_{2}$-DOX undergo an obvious decrease, which is consistent with a previous report [41].

The TG analysis results of $\mathrm{Fe}_{3} \mathrm{O}_{4} @ \mathrm{mSiO}_{2}, \mathrm{Fe}_{3} \mathrm{O}_{4} @ \mathrm{mSiO}-\mathrm{DOX}$ and $\mathrm{CS} / \mathrm{Fe}_{3} \mathrm{O}_{4} @ \mathrm{mSiO} \mathrm{O}_{2}-\mathrm{DOX}$ are shown in Fig. 6. One can see that the loss of physically adsorbed water on the samples occurred in the temperature range of $50-100^{\circ} \mathrm{C}$. As shown in Fig. 6a, there is about $4.82 \%$ weight loss for the $\mathrm{Fe}_{3} \mathrm{O}_{4} @ \mathrm{mSiO}_{2}$, this may be due to the decomposition of small amount of remaining 1,3,5-trimethylbenzene. While probably because of the decomposition of DOX, the curve of $\mathrm{Fe}_{3} \mathrm{O}_{4} @ \mathrm{mSiO}_{2}-\mathrm{DOX}$ nanoparticles shows a weight loss of $13.99 \%$ (Fig. 6b). In comparison, the weight loss of $\mathrm{CS} / \mathrm{Fe}_{3} \mathrm{O}_{4} @ \mathrm{mSiO}_{2}-\mathrm{DOX}$ is about 29.09\% (Fig. 6c), the increased amount (15.1\%) could 
attribute to the decomposition of CS. These results show that DOX has loaded into $\mathrm{Fe}_{3} \mathrm{O}_{4} @ \mathrm{mSiO}_{2}$ and CS has wrapped onto the surface of $\mathrm{CS} / \mathrm{Fe}_{3} \mathrm{O}_{4} @ \mathrm{mSiO}_{2}-\mathrm{DOX}$ successfully.

The structures of the nanoparticles were characterized by FT-IR. As shown in Fig. 7, the signals that appear around $3400 \mathrm{~cm}^{-1}$ may be attributed to the stretching vibration of $-\mathrm{OH}$, and the characteristic peaks at $580 \mathrm{~cm}^{-1}$ can be assigned to the $\mathrm{Fe}-\mathrm{O}$ vibration of $\mathrm{Fe}_{3} \mathrm{O}_{4}$ [33]. In Fig. 7a, the peaks around $1616 \mathrm{~cm}^{-1}$ and $1367 \mathrm{~cm}^{-1}$ are suggested to be caused by the stretching vibration of $-\mathrm{C}=\mathrm{O}$ and $-\mathrm{C}-\mathrm{O}$ bonds of OA. While in Fig. 7b-d, the typical absorption peaks at 1089 and $797 \mathrm{~cm}^{-1}$ were the stretching vibration of $\mathrm{Si}-\mathrm{O}-\mathrm{Si}$ and $\mathrm{Si}-\mathrm{O}$ [42], which indicated that the $\mathrm{mSiO}_{2}$ has coated onto $\mathrm{Fe}_{3} \mathrm{O}_{4}$ nanoparticles. The peaks at 1408 and $1730 \mathrm{~cm}^{-1}$ could be assigned to the quinone and 13-carbonyl vibration of DOX (Fig. 7b) [6], revealing the DOX has been loaded into $\mathrm{Fe}_{3} \mathrm{O}_{4} @ \mathrm{mSiO}_{2}$ nanocomposites. In Fig. 7c, the absorption peaks at 1652 and $1560 \mathrm{~cm}^{-1}$ correspond to the amide I and amide II of CS. What's more, the characteristic peak at $1730 \mathrm{~cm}^{-1}$ still existed. All these results proved that the CS wrapped the $\mathrm{Fe}_{3} \mathrm{O}_{4} @ \mathrm{mSiO}_{2}$-DOX successfully.

To further confirm the successful preparation of $\mathrm{CS} / \mathrm{Fe}_{3} \mathrm{O}_{4} @ \mathrm{mSiO}_{2}-\mathrm{DOX}$, the samples were further characterized by UV-vis. In Fig. 8, the as-prepared $\mathrm{Fe}_{3} \mathrm{O}_{4} @ \mathrm{mSiO}_{2}$ nanocomposites solution was light brown in color and showed no absorption band, while the DOX solution was light pink in color and showed a typical absorption maxima at $\lambda_{\max } 482 \mathrm{~nm}$, which can also be found in the spectra of $\mathrm{Fe}_{3} \mathrm{O}_{4} @ \mathrm{mSiO}_{2}-\mathrm{DOX}$ and $\mathrm{CS} / \mathrm{Fe}_{3} \mathrm{O}_{4} @ \mathrm{mSiO}_{2}$-DOX, indicating that the DOX has loaded into the mesoporous of $\mathrm{Fe}_{3} \mathrm{O}_{4} @ \mathrm{mSiO}_{2}$. In addition, the UV-vis spectra of $\mathrm{Fe}_{3} \mathrm{O}_{4} @ \mathrm{mSiO}_{2}-\mathrm{DOX}$ and $\mathrm{CS} / \mathrm{Fe}_{3} \mathrm{O}_{4} @ \mathrm{mSiO}_{2}-\mathrm{DOX}$ are similar to each other, which revealed that the CS would not affect the characteristic peak of DOX. All of these are consistent with the results of FT-IR that the $\mathrm{CS} / \mathrm{Fe}_{3} \mathrm{O}_{4} @ \mathrm{mSiO}_{2}-\mathrm{DOX}$ nanoparticles have been successfully synthesized. 
Fig. 9 presents the magnetization characterization of $\mathrm{Fe}_{3} \mathrm{O}_{4} @ \mathrm{mSiO}_{2}, \mathrm{Fe}_{3} \mathrm{O}_{4} @ \mathrm{mSiO}_{2}-\mathrm{DOX}$ and $\mathrm{CS} / \mathrm{Fe}_{3} \mathrm{O}_{4} @ \mathrm{mSiO}_{2}-\mathrm{DOX}$ at room temperature. We can see that the saturation magnetizations $\left(\mathrm{M}_{\mathrm{s}}\right)$ of $\mathrm{Fe}_{3} \mathrm{O}_{4} @ \mathrm{mSiO}_{2}, \mathrm{Fe}_{3} \mathrm{O}_{4} @ \mathrm{mSiO}_{2}-\mathrm{DOX}$ and $\mathrm{CS} / \mathrm{Fe}_{3} \mathrm{O}_{4} @ \mathrm{mSiO}_{2}-\mathrm{DOX}$ are about 43.72, 35.66, and 13.50 emu/g, respectively, and are ascribed to the non-magnetic $\mathrm{mSiO}_{2}$, DOX and CS. Furthermore, the inset ( I ) of Fig. 9 shows an enlarged section of the magnetization plot near the zero magnetic fields. Saturation remanence $\left(\mathrm{M}_{\mathrm{r}}\right)$ and coercivity $\left(\mathrm{H}_{\mathrm{c}}\right)$ can be determined from the intersection of the hysteresis loop with two axes at $0.62 \mathrm{emu} / \mathrm{g}$ and $0.19 \mathrm{Oe}$, respectively. These two values indicate that a rather low residual magnetization is present when the external magnetic field is removed and that low-intensity magnetic field is required to reduce the magnetization to zero. These results reveal that the $\mathrm{CS} / \mathrm{Fe}_{3} \mathrm{O}_{4} @ \mathrm{mSiO}_{2}-\mathrm{DOX}$ is in the superparamagnetic state [40,43]. Moreover, the inset ( II ) of Fig. 9 shows a typical magnetic separation of $\mathrm{CS} / \mathrm{Fe}_{3} \mathrm{O}_{4} @ \mathrm{mSiO}_{2}$ - $\mathrm{DOX}$ dispersed in PBS solution (pH 7.4), when a magnet was placed outside the tube, the $\mathrm{CS} / \mathrm{Fe}_{3} \mathrm{O}_{4} @ \mathrm{mSiO}_{2}-\mathrm{DOX}$ was concentrated at the magnet site, whereas the solution became colorless. Therefore, it is expected that the $\mathrm{CS} / \mathrm{Fe}_{3} \mathrm{O}_{4} @ \mathrm{mSiO}_{2}-\mathrm{DOX}$ can be easily controlled by an external magnetic field, and then the drug can be easily delivered to the target area.

\section{2. $p H$ dependent drug release}

The drug loading content and loading efficiency are calculated to be $29.3 \%$ and $93.6 \%$, respectively. The DOX loading amount in our work was found to be much higher than those in earlier reports [44-46]. The in vitro release experiment of $\mathrm{Fe}_{3} \mathrm{O}_{4} @ \mathrm{mSiO}_{2}-\mathrm{DOX}$ and $\mathrm{CS} / \mathrm{Fe}_{3} \mathrm{O}_{4} @ \mathrm{mSiO}_{2}-\mathrm{DOX}$ was performed under $\mathrm{pH} 7.5,5.8$ and 4.0 at $37^{\circ} \mathrm{C}$. The results were shown in Fig. 10. For the $\mathrm{Fe}_{3} \mathrm{O}_{4} @ \mathrm{mSiO}_{2}$-DOX (Fig. 10a), complete DOX release was found to occur around $9 \mathrm{~h}$ and $18 \mathrm{~h}$ at $\mathrm{pH}$ 4.0 and 5.8. What's more, even under the weak alkaline condition ( $\mathrm{pH} 7.5$ ), up to $66.7 \%$ DOX was 
released within 48 hours. This confirmed that $\mathrm{Fe}_{3} \mathrm{O}_{4} @ \mathrm{mSiO}_{2}$-DOX without "gatekeeper" could cause sudden drug release or complete drug release in a short time. However, in Fig. 10b, all of the release behaviors at different $\mathrm{pH}$ displayed a two-step release. The first-step occurred within $10 \mathrm{~h}$ and in this period of time the DOX was released quickly and with the $\mathrm{pH}$ value decrease the DOX release (\%) increased. However, in the second-step release, the drug release rates significantly decreased and leveled off, the values of DOX release (\%) within $48 \mathrm{~h}$ at $\mathrm{pH} 4.0,5.8$ and 7.5 were $86.1 \%, 71.0 \%$ and $24.9 \%$, respectively. Consequently, the pH-triggered DOX release will decrease the drug loss during blood circulation and improve intracellular drug release at tumor cells.

To learn more about the release behavior, the release data were also analyzed by the First-order and Higuchi models [47,48]. As can be seen in Fig. 10c, the DOX release data were subjected to First-order model and the regression $\left(R^{2}\right)$ values for $\mathrm{pH} 4.0,5.8$ and 7.5 were found to be $0.160,0.146$ and 0.148 , respectively. Next, the data was subjected to Higuchi model which was frequently used to study drug release kinetics from an insoluble, porous carrier matrix to find out whether diffusion is involved in drug release (Fig. 10d). The regression $\left(R^{2}\right)$ values for $\mathrm{pH} 4.0,5.8$ and 7.5 were found to be $0.858,0.839$ and 0.864 , respectively, indicating that a purely diffusion-controlled process played a major role on DOX release from $\mathrm{CS} / \mathrm{Fe}_{3} \mathrm{O}_{4} @ \mathrm{mSiO}_{2}-\mathrm{DOX}$ [48]. That is to say, when $\mathrm{CS} / \mathrm{Fe}_{3} \mathrm{O}_{4} @ \mathrm{mSiO}_{2}$-DOX were immersed in the release medium, the "gatekeeper" was degraded most quickly, making the highest and fastest dissolution as well as the release rate, which resulted in most of the loaded drug released. After that, the drug release is determined just by the mesoporous structure of the host so as to maintain the drug dose. All the results revealed that the $\mathrm{CS} / \mathrm{Fe}_{3} \mathrm{O}_{4} @ \mathrm{mSiO}_{2}-\mathrm{DOX}$ could be a smart targeted drug delivery system.

\subsection{Cytotoxicity analysis}


The cytotoxicity of $\mathrm{Fe}_{3} \mathrm{O}_{4} @ \mathrm{mSiO}_{2}$, free DOX and $\mathrm{CS} / \mathrm{Fe}_{3} \mathrm{O}_{4} @ \mathrm{mSiO}_{2}$-DOX were studied using MTT assay and the data was depicted in Fig. 11. Within the concentration range, as high as $120 \mu \mathrm{g} / \mathrm{mL}$, $\mathrm{Fe}_{3} \mathrm{O}_{4} @ \mathrm{mSiO}_{2}$ nanocomposites had no obvious adverse effect on cell viability after incubation for $24 \mathrm{~h}$, which demonstrates that the $\mathrm{Fe}_{3} \mathrm{O}_{4} @ \mathrm{mSiO}_{2}$ nanocomposites have negligible cytotoxicity. In contrast, the relative viability of cells for $\mathrm{CS} / \mathrm{Fe}_{3} \mathrm{O}_{4} @ \mathrm{mSiO}_{2}$-DOX was relatively lower than the $\mathrm{Fe}_{3} \mathrm{O}_{4} @ \mathrm{mSiO}_{2}$. This could be explained by the fact that the DOX released from $\mathrm{CS} / \mathrm{Fe}_{3} \mathrm{O}_{4} @ \mathrm{mSiO}_{2}-\mathrm{DOX}$ influenced the cell viability. Moreover, the cytotoxicity of $\mathrm{CS} / \mathrm{Fe}_{3} \mathrm{O}_{4} @ \mathrm{mSiO}_{2}-\mathrm{DOX}$ was concentration-dependent that the relative cell viability decreased with the increasing concentration of $\mathrm{CS} / \mathrm{Fe}_{3} \mathrm{O}_{4} @ \mathrm{mSiO}_{2}-\mathrm{DOX}$ and the $\mathrm{IC}_{50}$ was about $80 \mu \mathrm{g} / \mathrm{mL}$. As a comparison, the cytotoxicity of DOX of same concentration with $\mathrm{CS} / \mathrm{Fe}_{3} \mathrm{O}_{4} @ \mathrm{mSiO}_{2}$-DOX was also studied. The results showed that the cytotoxicity of the released DOX from $\mathrm{CS} / \mathrm{Fe}_{3} \mathrm{O}_{4} @ \mathrm{mSiO}_{2}-\mathrm{DOX}$ was stronger than the free DOX at the same concentration for the $\mathrm{Fe}^{3+}$ had slightly bigger toxicity over cells then $\mathrm{Fe}^{2+}$ due to the tendency of oxygen capture from the cells $[49,50]$.

What's more, the fluorescence images (the green for living cells and the red for dead cells) of HepG2 cells treated with culture medium as control, $\mathrm{Fe}_{3} \mathrm{O}_{4} @ \mathrm{mSiO}_{2}$, free $\mathrm{DOX}$ and $\mathrm{CS} / \mathrm{Fe}_{3} \mathrm{O}_{4} @ \mathrm{mSiO}_{2}-\mathrm{DOX}$ were shown in Fig. 12. It was observed that almost no red fluorescence was found in the images of cells treated with $\mathrm{Fe}_{3} \mathrm{O}_{4} @ \mathrm{mSiO}_{2}$, and more red fluorescence was found in the images of cells treated with $\mathrm{CS} / \mathrm{Fe}_{3} \mathrm{O}_{4} @ \mathrm{mSiO}_{2}$-DOX than the free DOX. This is consistent with the results of cytotoxicity analysis. All the results confirmed that the $\mathrm{Fe}_{3} \mathrm{O}_{4} @ \mathrm{mSiO}_{2}$ nanocomposites as drug carriers were non-toxic and revealed the potential of $\mathrm{CS} / \mathrm{Fe}_{3} \mathrm{O}_{4} @ \mathrm{mSiO}_{2}-\mathrm{DOX}$ to be used for cancer therapy.

\section{Conclusion}


In summary, we have demonstrated a pH-responsive controlled-release system using a smart switch (CS) wrapped core-shell $\mathrm{Fe}_{3} \mathrm{O}_{4} @ \mathrm{mSiO}_{2}$ nanocomposites for targeted drug delivery. The $\mathrm{Fe}_{3} \mathrm{O}_{4} @ \mathrm{mSiO}_{2}$ nanocarriers had a suitable size, good magnetic responsibility as well as the high pore volume and large surface area (high drug loading capacity). The DOX had loaded into the mesoporous of $\mathrm{Fe}_{3} \mathrm{O}_{4} @ \mathrm{mSiO}_{2}$ at a drug loading efficiency of $93.6 \%$ via the electrostatic interaction. Owing to the degradation of the "gatekeeper" at $\mathrm{pH}<6.0$, the $\mathrm{CS} / \mathrm{Fe}_{3} \mathrm{O}_{4} @ \mathrm{mSiO}_{2}-\mathrm{DOX}$ had excellent pH-sensitivity, and the values of DOX release (\%) within $48 \mathrm{~h}$ at $\mathrm{pH} 4.0$ and 5.8 were $86.1 \%$ and $71.0 \%$, respectively. Furthermore, the in vitro MTT assay against $\mathrm{HepG} 2$ cells revealed that the $\mathrm{CS} / \mathrm{Fe}_{3} \mathrm{O}_{4} @ \mathrm{mSiO}_{2}-\mathrm{DOX}$ exhibited high anti-tumor activity while the $\mathrm{Fe}_{3} \mathrm{O}_{4} @ \mathrm{mSiO}_{2}$ had no obviously cytotoxic effect on HepG2 cells even at a concentration of $120 \mu \mathrm{g} / \mathrm{mL}$. Considering the high specificity, good controlled release performance and the effective inhibition of tumor growth, the $\mathrm{CS} / \mathrm{Fe}_{3} \mathrm{O}_{4} @ \mathrm{mSiO}$ - $\mathrm{DOX}$ can be employed as a potential candidate for targeted cancer treatment.

\section{Acknowledgments}

The authors are grateful for National Science Foundation of China (No.50972060), the Fundamental Research Funds for the Central Universities (No.30920130112003) and the Priority Academic Program Development of Jiangsu Higher Education Institutions.

\section{References}

[1] J. Hwang, E. Lee, J. Kim, Y. Seo, K.H. Lee, J.W. Hong, A.A. Gilad, H. Park, J. Choi, Effective delivery of immunosuppressive drug molecules by silica coated iron oxide nanoparticles, Colloid. Surface. B 142 (2016) 290-296.

[2] P. Liu, D. Wang, Y. Zhou, H. Wang, H. Yin, S. Ai, DNA methyltransferase detection based on digestion triggering the combination of poly adenine DNA with gold nanoparticles, Biosens. Bioelectro. 80 (2016) 74-78.

[3] M.S. Haider, G.N. Shao, S.M. Imran, S.S. Park, N. Abbas, M.S. Tahir, M. Hussain, W. Bae, H.T. Kim, Aminated polyethersulfone-silver nanoparticles (AgNPs-APES) composite membranes with controlled silver ion release for antibacterial and water treatment applications, Mat. Sci. Eng. C-Mater. 62 (2016) 732-745. 
[4] N. Shahabadi, M. Falsafi, K. Mansouri, Improving antiproliferative effect of the anticancer drug cytarabine on human promyelocytic leukemia cells by coating on $\mathrm{Fe}_{3} \mathrm{O}_{4} @ \mathrm{SiO}_{2}$ nanoparticles, Colloid. Surface. B 141 (2016) 213-222.

[5] Z. Cheng, Y. Dai, X. Kang, C. Li, S. Huang, H. Lian, Z. Hou, P. Ma, J. Lin, Gelatin-encapsulated iron oxide nanoparticles for platinum (IV) prodrug delivery, enzyme-stimulated release and MRI, Biomaterials 35 (2014) 6359-6368.

[6] J. Wu, S. Xu, W. Jiang, Y. Shen, M. Pu, Facile preparation of a pH-sensitive nano-magnetic targeted system to deliver doxorubicin to tumor tissues, Biotechnol. Lett. 3 (2015) 585-591.

[7] N. Sudha, S. Yousuf, E.V.M.V. Israel, M.S. Paulraj, P. Dhanaraj, On the accessibility of surface-bound drugs on magnetic nanoparticles. Encapsulation of drugs loaded on modified dextran-coated superparamagnetic iron oxide by $\beta$-cyclodextrin, Colloid. Surface. B 141 (2016) 423-428.

[8] G.R. Mahdavinia, H. Etemadi, In situ synthesis of magnetic CaraPVA IPN nanocomposite hydrogels and controlled drug release, Mat. Sci. Eng. C-Mater. 45 (2014) 250-260.

[9] G.R. Mahdavinia, Z. Rahmani, S. Karami, A. Pourjavadi, Magnetic/pH-sensitive kappa-carrageenan/sodium alginate hydrogel nanocomposite beads: preparation, swelling behavior, and drug delivery, J. Biomat. Sci.-Polyme. 25 (2014) 1891-1906.

[10] G.R. Mahdavinia, S. Ettehadi, M. Amini, M. Sabzi, Synthesis and characterization of hydroxypropyl methylcellulose-g-poly(acrylamide)/LAPONITE (R) RD nanocomposites as novel magnetic- and pH-sensitive carriers for controlled drug release, RSC Adv. 5 (2015) 44516-44523.

[11] T.K. Jain, M.A. Morales, S.K. Sahoo, D.L. Leslie-Pelecky, V. Labhasetwar, Iron oxide nanoparticles for sustained delivery of anticancer agents, Mol. Pharm. 2 (2005) 194-205.

[12] C.C. Berry, A.S.G. Curtis, Functionalisation of magnetic nanoparticles for applications in biomedicine, J. Phys. D. Appl. Phys. 36 (2003) 198-206.

[13] T. Neuberger, B. Schopf, Superparamagnetic nanoparticles for biomedical applications: possibilities and limitations for new drug delivery system, J. Magn. Magn. Mater. 293 (2005) 483-96.

[14] A.K. Gupta, M. Gupta, Synthesis and surface engineering of iron oxide nanoparticles for biomedical applications, Biomaterials 26 (2005) 3995-4021.

[15] S. Xuan, F. Wang, J.M.Y. Lai, K.W.Y. Sham, Y.X.J. Wang, S.F. Lee, J.C. Yu, C.H.K. Cheng, K.C.F. Leung, Synthesis of biocompatible, mesoporous $\mathrm{Fe}_{3} \mathrm{O}_{4}$ nano/microspheres with large surface area for magnetic resonance imaging and therapeutic applications, ACS Appl. Mater. Inter. 3 (2011) 237-244.

[16] L.A. Harris, J.D. Goff, A.Y. Carmichael, J.S. Riffle, J.J. Harburn, T.G. St. Pierre, M. Saunders, Magnetite nanoparticle dispersions stabilized with triblock copolymers, Chem. Mater. 15 (2003) 1367-1377.

[17] E. Yu, I. Galiana, R. Martínez-Máñez, P. Stroeve, M.D. Marcos, E. Aznar, F. Sancenón, J.R. Murguía, P. Amorós, Poly(N-isopropylacrylamide)-gated $\mathrm{Fe}_{3} \mathrm{O}_{4} / \mathrm{SiO}_{2}$ core shell nanoparticles with expanded mesoporous structures for the temperature triggered release of lysozyme, Colloid. Surface. B 135 (2015) 652-660.

[18] F. Tian, G. Chen, P. Yi, J. Zhang, A. Li, J. Zhang, L. Zheng, Z. Deng, Q. Shi, R. Peng, Q. Wang, Fates of $\mathrm{Fe}_{3} \mathrm{O}_{4}$ and $\mathrm{Fe}_{3} \mathrm{O}_{4} @ \mathrm{SiO}_{2}$ nanoparticles in human mesenchymal stem cells assessed by synchrotron radiation-based techniques, Biomaterials 35 (2014) 6412-6421.

[19] P. Tartaj, T. González-Carreño, C.J. Serna, Single-step nanoengineering of silica coated maghemite hollow spheres with tunable magnetic properties, Adv. Mater. 13 (2001) 1620-1624. 
[20] S. Santra, R. Tapec, N. Theodoropoulou, J. Dobson, A. Hebard, W. Tan, Synthesis and characterization of silica-coated iron oxide nanoparticles in microemulsion: the effect of non-ionic surfactants, Langmuir 17 (2001) 2900-2906.

[21] Y. Zhao, B.G. Trewyn, I.I. Slowing, V.S.Y. Lin, Mesoporous silica nanoparticle-based double drug delivery system for glucose-responsive controlled release of insulin and cyclic AMP, J. Am. Chem. Soc. 131 (2009) 8398-8400.

[22] C. Argyo, V. Weiss, C. Bräuchle, T. Bein, Multifunctional mesoporous silica nanoparticles as a universal platform for drug delivery, Chem. Mater. 26 (2014) 435-451.

[23] X. Mei, D. Chen, N. Li, Q. Xu, J. Ge, H. Li, B. Yang, Y. Xu, J. Lu, Facile preparation of coating fluorescent hollow mesoporous silica nanoparticles with $\mathrm{pH}$-sensitive amphiphilic diblock copolymer for controlled drug release and cell imaging, Soft Matter. 8 (2012) 5309-5316.

[24] A. Rámila, B. Muños, J. Prez-Pariente, M. Vallet-Regí, Mesoporous MCM-41 as drug host system, J. Sol-Gel Sci. Techn. 26 (2003) 1199-1202.

[25] B. Chang, X. Sha, J. Guo, Y. Jiao, C. Wang, W. Yang, Thermo and pH dual responsive, polymer shell coated, magnetic mesoporous silica nanoparticles for controlled drug release, J. Mater. Chem. 21 (2011) 9239-9247.

[26] M.W. Ambrogio, C.R. Thomas, Y.-L. Zhao, J.I. Zink, J.F. Stoddart, Mechanized silica nanoparticles: a new frontier in theranostic nanomedicine, Accounts Chem. Res. 44 (2011) 903-913.

[27] Y. Kamachi, B.P. Bastakoti, S.M. Alshehri, N. Miyamoto, T. Nakato, Y. Yamauchi, Thermo-responsive hydrogels containing mesoporous silica toward controlled and sustainable releases, Mater. Lett. 168 (2016) 176-179.

[28] B. Xia, B. Wang, Z. Chen, Q. Zhang, J. Shi, Near-infrared light-triggered intracellular delivery of anticancer drugs using porous silicon nanoparticles conjugated with IR820 dyes, Adv. Mater. Interfaces 3 (2016) 1500715.

[29] Y. Zhu, W. Meng, H. Gao, N. Hanagata, Hollow mesoporous silica/poly(l-lysine) particles for codelivery of drug and gene with enzyme-triggered release property, J. Phys. Chem. C 115 (2011) 13630-13636.

[30] S. Angelos, N.M. Khashab, Y.-W. Yang, A. Trabolsi, H.A. Khatib, J.F. Stoddart, J.I. Zink, pH clock-operated mechanized nanoparticles, J. Am. Chem. Soc. 131 (2009) 12912-12914.

[31] Z. Liu, Y. Jiao, Y. Wang, C. Zhou, Z. Zhang, Polysaccharides-based nanoparticles as drug delivery systems, Adv. Drug Deliver. Rev. 60 (2008) 1650-1662.

[32] S. Al-Qadi, M. Alatorre-Meda, M. Martin-Pastor, P. Taboada, C. Remuñán-López, The role of hyaluronic acid inclusion on the energetics of encapsulation and release of a protein molecule from chitosan-based nanoparticles, Colloid. Surface. B 141 (2016) 223-232.

[33] J. Wu, Y. Wang, W. Jiang, S. Xu, R. Tian, Synthesis and characterization of recyclable clusters of magnetic nanoparticles as doxorubicin carriers for cancer therapy, Appl. Surf. Sci. 321 (2014) 43-49.

[34] S. Manchun, K. Cheewatanakornkool, C.R. Dass, P. Sriamornsak, Novel pH-responsive dextrin nanogels for doxorubicin delivery to cancer cells with reduced cytotoxicity to cardiomyocytes and stem cells, Carbohyd. Polym. 114 (2014) 78-86.

[35] D.-G. Ahn, J. Lee, S.-Y. Park, Y.-J. Kwark, K.Y. Lee, Doxorubicin-loaded alginate-g-poly(N-isopropylacrylamide) micelles for cancer imaging and therapy, ACS Appl. Mater. Inter. 6 (2014) 22069-22077.

[36] S. Wu, W. Jiang, Z. Sun, J. Dai, L. Liu, F. Li, Preparation of novel magnetic fluorescent nanospheres by sonochemical method, J. Magn. Magn. Mater. 323 (2011) 2170-2173. 
[37] J. Zhang, X. Li, J.M. Rosenholm, H.-C. Gu, Synthesis and characterization of pore size-tunable magnetic mesoporous silica nanoparticles, J. Colloid Interf. Sci. 361 (2011) 16-24.

[38] S.E. Pratsinis, S. Vemury, Particle formation in gases: a review, Powder Technol. 88 (1996) 267-273.

[39] P.T. Tanev, T.J. Pinnavaia, Mesoporous silica molecular sieves prepared by ionic and neutral surfactant templating: a comparison of physical properties, Chem. Mater. 8 (1996) 2068-2079.

[40] J. Wu, W. Jiang, A. Deng, Y. Shen, W. Jiang, R. Tian, Facile synthesis of magnetic fluorescence probe for recyclable displacement detection of $\mathrm{Hg}^{2+}$ in aqueous solutions and living cells, Sensor. Actuat. B-Chem. 234 (2016) 691-702.

[41] W. Guo, C. Yang, L. Cui, H. Lin, F. Qu, An enzyme-responsive controlled release system of mesoporous silica coated with konjac oligosaccharide, Langmuir 30 (2014) 243-249.

[42] A. Pourjavadi, Z.M. Tehrani, Mesoporous silica nanoparticles (MCM-41) coated PEGylated chitosan as a $\mathrm{pH}$ responsive nanocarrier for triggered release of erythromycin, Int. J. Polym. Mater. 63 (2014) 692-697.

[43] S. Sun, H. Zeng, D.B. Robinson, S. Raoux, P.M. Rice, S.X. Wang, G. Li, Monodis-perse $\mathrm{MFe}_{2} \mathrm{O}_{4}$ (M = Fe, Co, Mn) nanoparticles, J. Am. Chem. Soc. 126 (2004) 273-279.

[44] J. Yu, Y. Zhou, W. Chen, J. Ren, L. Zhang, L. Lu, G. Luo, H. Huang, Preparation, Characterization and evaluation of $\alpha$-tocopherol succinate-modified dextran micelles as potential drug carriers, Materials 8 (2015) 6685-6696.

[45] C. Chuang, C. Li, A. Prasannan, B. Truong-Le, P. Hong, Preparation of a drug carrier through $\alpha$-cyclodextrin-induced micellization of poly( $\varepsilon$-caprolactone-block-4-vinylpyridine) for controlled delivery of doxorubicin, J. Polym. Res. 22 (2015) 206.

[46] X. Luo, H. Zhang, Z. Cao, N. Cai, Y. Xue, F. Yu, A simple route to develop transparent doxorubicin-loaded nanodiamonds/cellulose nanocomposite membranes as potential wound dressings, Carbohydrate Polymers 143 (2016) 231-238.

[47] H. Zhang, K. Zou, S. Guo, X. Duan, Nanostructural drug inorganic clay composites: structure, thermal property and in vitro release of captopril-intercalated $\mathrm{Mg}$-Al layered double hydroxides, $\mathrm{J}$. Solid State Chem. 179 (2006) 1792-1801.

[48] T. Higuchi, Mechanism of sustained-action medication: theoretical analysis of rate of release of solid drugs dispersed in solid matrices, J. Pharm. Sci. 52 (1963) 1145-1149.

[49] H.S. Yoo, T.G. Park, Folate-receptor-targeted delivery of doxorubicin nano-aggregates stabilized by doxorubicin-PEG-folate conjugate, J. Control. Release100 (2004) 247-256.

[50] J. Varshosaz, H. Sadeghi-aliabadi, S. Ghasemi, B. Behdadfar, Use of magneticfolate-dextran-retinoic acid micelles for dual targeting of doxorubicin in breastcancer, Biomed. Res. Int 2013 (2013) 1-16.

\section{Figures caption:}

Fig. 1. Illustration of the preparation and controlled release process of $\mathrm{CS} / \mathrm{Fe}_{3} \mathrm{O}_{4} @ \mathrm{mSiO}_{2}-\mathrm{DOX}$.

Fig. 2. TEM image and the size distribution of (a,b) $\mathrm{Fe}_{3} \mathrm{O}_{4}$, (c,d) $\mathrm{Fe}_{3} \mathrm{O}_{4} @ \mathrm{mSiO}_{2}$ and (e,f) $\mathrm{CS} / \mathrm{Fe}_{3} \mathrm{O}_{4} @ \mathrm{mSiO}_{2}-\mathrm{DOX}$.

Fig. 3. The hydrodynamic dynamic diameters of $\mathrm{Fe}_{3} \mathrm{O}_{4} @ \mathrm{mSiO}_{2}$ and $\mathrm{CS} / \mathrm{Fe}_{3} \mathrm{O}_{4} @ \mathrm{mSiO}_{2}-\mathrm{DOX}$. The 
inset table is zeta potential data of the samples.

Fig. 4. (a) Nitrogen adsorption-desorption isotherms and (b) pore size distribution of $\mathrm{Fe}_{3} \mathrm{O}_{4} @ \mathrm{mSiO}_{2}$ and $\mathrm{CS} / \mathrm{Fe}_{3} \mathrm{O}_{4} @ \mathrm{mSiO}_{2}-\mathrm{DOX}$. The inset table is the pore parameters of the samples.

Fig. 5. (a) Wide angle $\mathrm{XRD}$ patterns of $\mathrm{Fe}_{3} \mathrm{O}_{4}, \mathrm{Fe}_{3} \mathrm{O}_{4} @ \mathrm{mSiO}_{2}, \mathrm{Fe}_{3} \mathrm{O}_{4} @ \mathrm{mSiO}_{2}-\mathrm{DOX}$ and $\mathrm{CS} / \mathrm{Fe}_{3} \mathrm{O}_{4} @ \mathrm{mSiO}_{2}-\mathrm{DOX}$; (b) small angle XRD patterns of $\mathrm{Fe}_{3} \mathrm{O}_{4} @ \mathrm{mSiO}_{2}, \mathrm{Fe}_{3} \mathrm{O}_{4} @ \mathrm{mSiO}$ - $\mathrm{DOX}$ and $\mathrm{CS} / \mathrm{Fe}_{3} \mathrm{O}_{4} @ \mathrm{mSiO}_{2}-\mathrm{DOX}$.

Fig. 6. TG analysis results of (a) $\mathrm{Fe}_{3} \mathrm{O}_{4} @ \mathrm{mSiO}_{2}, \quad$ (b) $\mathrm{Fe}_{3} \mathrm{O}_{4} @ \mathrm{mSiO}_{2}-\mathrm{DOX}$ and (c) $\mathrm{CS} / \mathrm{Fe}_{3} \mathrm{O}_{4} @ \mathrm{mSiO}_{2}-\mathrm{DOX}$.

Fig. 7. FT-IR spectra of (a) $\mathrm{Fe}_{3} \mathrm{O}_{4}$, (b) $\mathrm{Fe}_{3} \mathrm{O}_{4} @ \mathrm{mSiO}_{2}$, (c) $\mathrm{Fe}_{3} \mathrm{O}_{4} @ \mathrm{mSiO}_{2}-\mathrm{DOX}$ and (d) $\mathrm{CS} / \mathrm{Fe}_{3} \mathrm{O}_{4} @ \mathrm{mSiO}_{2}-\mathrm{DOX}$

Fig. 8. UV-vis spectra of $\mathrm{Fe}_{3} \mathrm{O}_{4} @ \mathrm{mSiO}_{2}, \mathrm{DOX}, \mathrm{Fe}_{3} \mathrm{O}_{4} @ \mathrm{mSiO}_{2}-\mathrm{DOX}$ and $\mathrm{CS} / \mathrm{Fe}_{3} \mathrm{O}_{4} @ \mathrm{mSiO}_{2}-\mathrm{DOX}$ as well as their corresponding solution colors.

Fig. 9. VSM measurement results of $\mathrm{Fe}_{3} \mathrm{O}_{4} @ \mathrm{mSiO}_{2}, \quad \mathrm{Fe}_{3} \mathrm{O}_{4} @ \mathrm{mSiO}_{2}-\mathrm{DOX}$ and $\mathrm{CS} / \mathrm{Fe}_{3} \mathrm{O}_{4} @ \mathrm{mSiO}_{2}-\mathrm{DOX}$. Insets: ( I ) the curve of $\mathrm{CS} / \mathrm{Fe}_{3} \mathrm{O}_{4} @ \mathrm{mSiO}_{2}-\mathrm{DOX}$ with the external magnetic field is near zero, wherein the two markers present the values of saturation remanence $\left[\mathrm{M}_{\mathrm{rs}}=0.62 \mathrm{emu} / \mathrm{g}\right]$ and coercivity $\left[\mathrm{H}_{\mathrm{c}}=0.19 \mathrm{Oe}\right]$ respectively; ( II ) photographs of dispersions of $\mathrm{CS} / \mathrm{Fe}_{3} \mathrm{O}_{4} @ \mathrm{mSiO}_{2}-\mathrm{DOX}$ after a magnet placed on the bottom of the glass bottle for $15 \mathrm{~min}$.

Fig. 10. In vitro cumulative release of $\mathrm{DOX}$ from (a) $\mathrm{Fe}_{3} \mathrm{O}_{4} @ \mathrm{mSiO}_{2}-\mathrm{DOX}$, (b) $\mathrm{CS} / \mathrm{Fe}_{3} \mathrm{O}_{4} @ \mathrm{mSiO}_{2}-\mathrm{DOX}$ at $37^{\circ} \mathrm{C}$ in PBS buffer at $\mathrm{pH}$ 7.5, 5.8 and 4.0, and (c) First-order model and (d) Higuchi model of DOX released from $\mathrm{CS} / \mathrm{Fe}_{3} \mathrm{O}_{4} @ \mathrm{mSiO}_{2}-\mathrm{DOX}$. Results are expressed as the mean \pm SD of three independent experiments.

Fig. 11. Cytotoxicity evaluation of $\mathrm{Fe}_{3} \mathrm{O}_{4} @ \mathrm{mSiO}_{2}, \mathrm{DOX}$ and $\mathrm{CS} / \mathrm{Fe}_{3} \mathrm{O}_{4} @ \mathrm{mSiO}_{2}-\mathrm{DOX}$ by MTT assay 
on HepG2 cells after $24 \mathrm{~h}$ treatment. Data were expressed as mean $\pm \mathrm{SD}$.

Fig. 12. Fluorescence images of HepG2 cells incubated with culture medium as control, $\mathrm{Fe}_{3} \mathrm{O}_{4} @ \mathrm{mSiO}_{2}$, DOX and $\mathrm{CS} / \mathrm{Fe}_{3} \mathrm{O}_{4} @ \mathrm{mSiO}_{2}-\mathrm{DOX}$ at a concentration of $120 \mu \mathrm{g} / \mathrm{mL}$. Cells were counterstained with AO (for living cells, the green) and EB (for dead cells, the red). 
CS
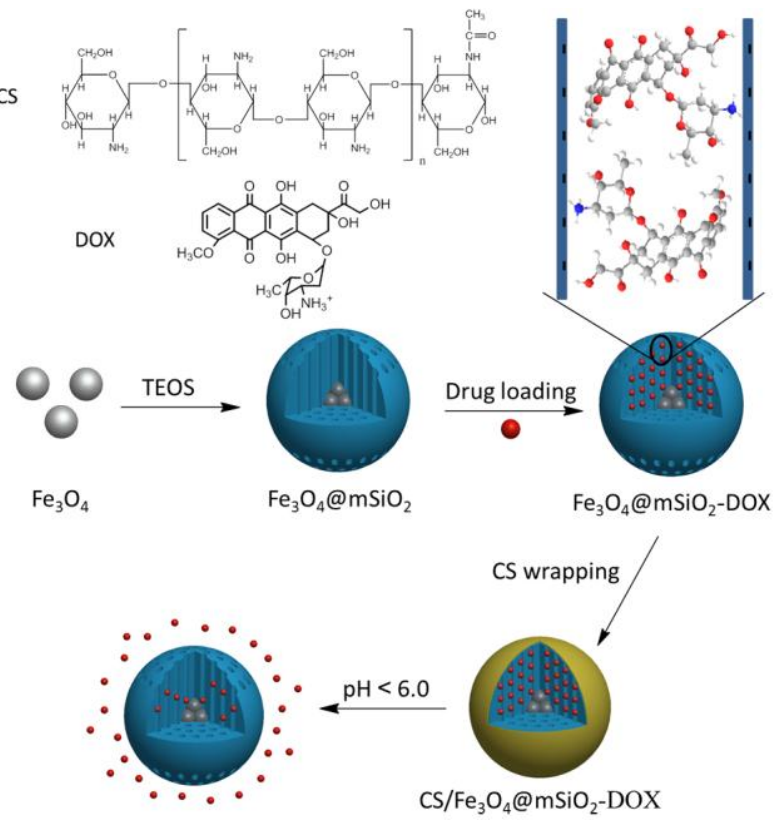

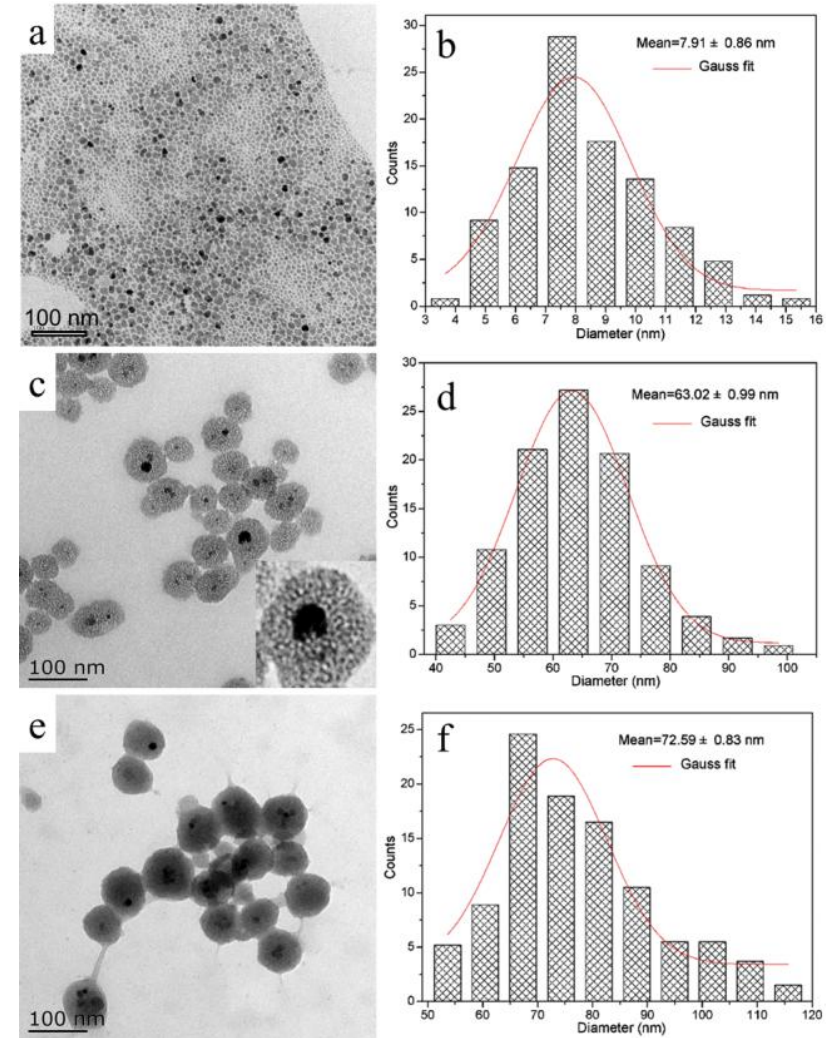


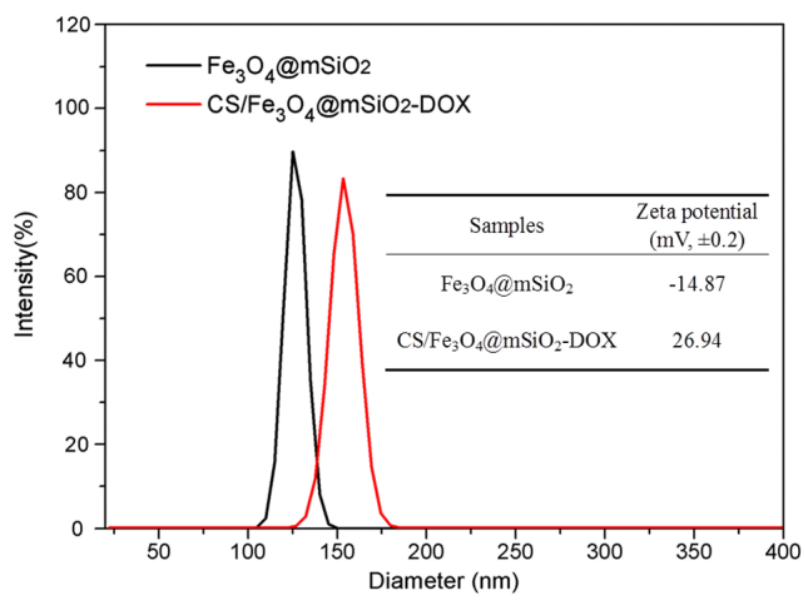



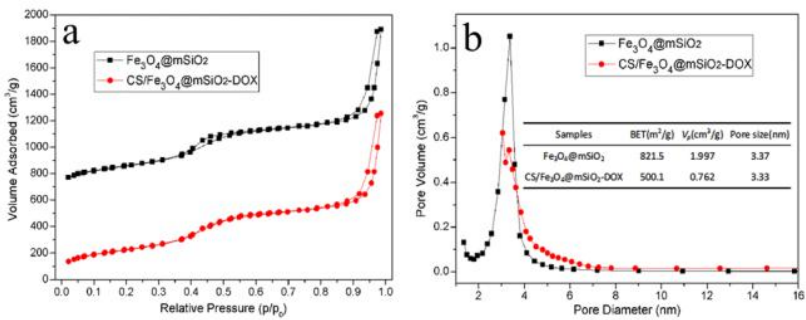


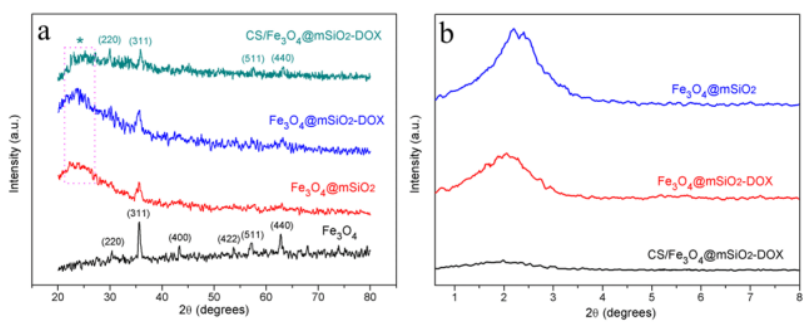




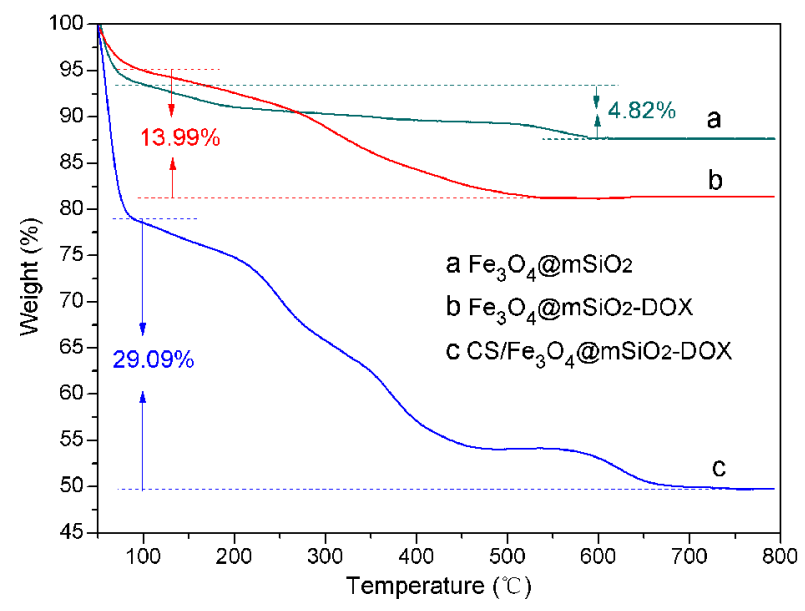




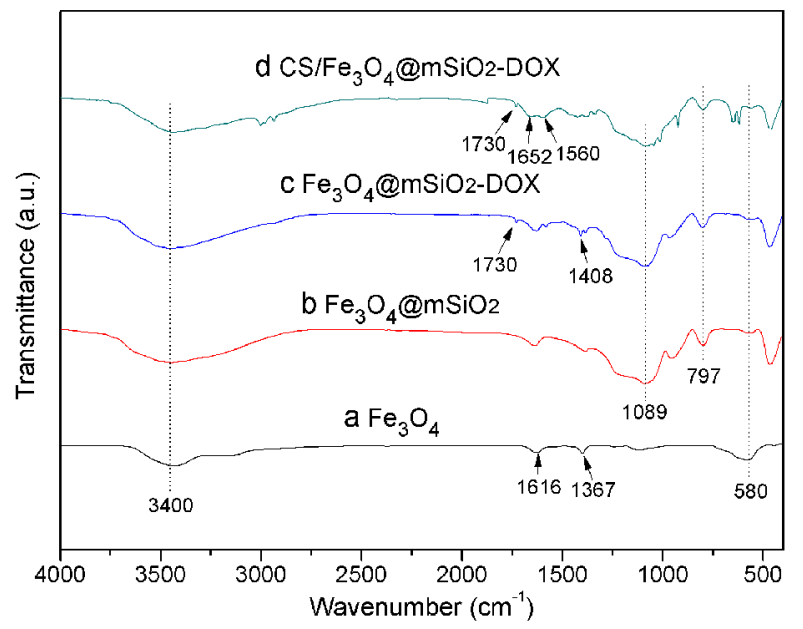




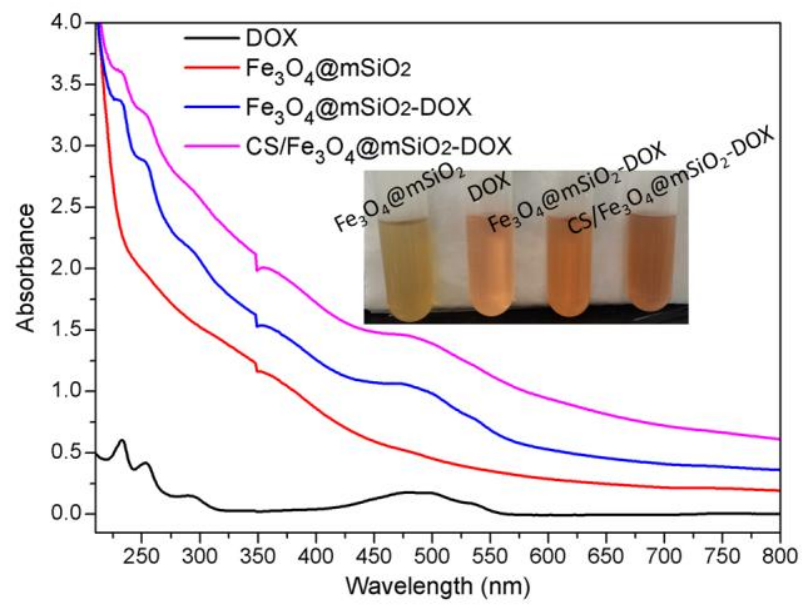




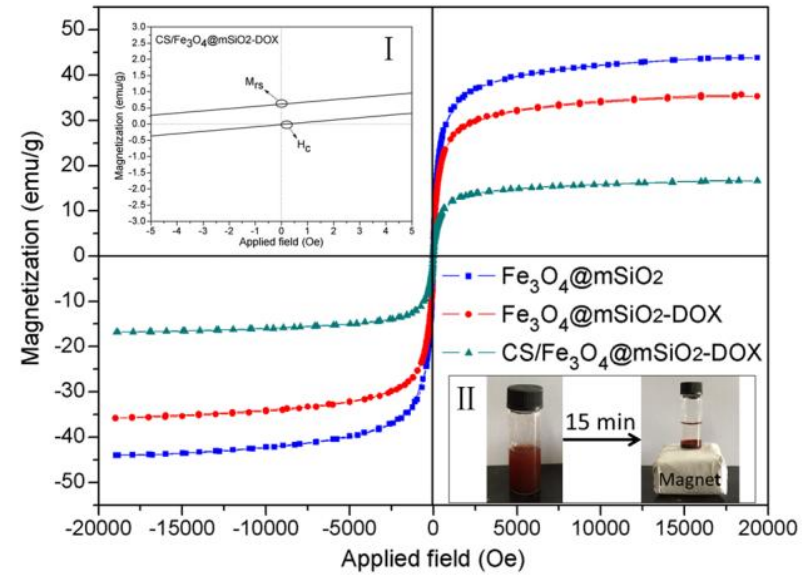



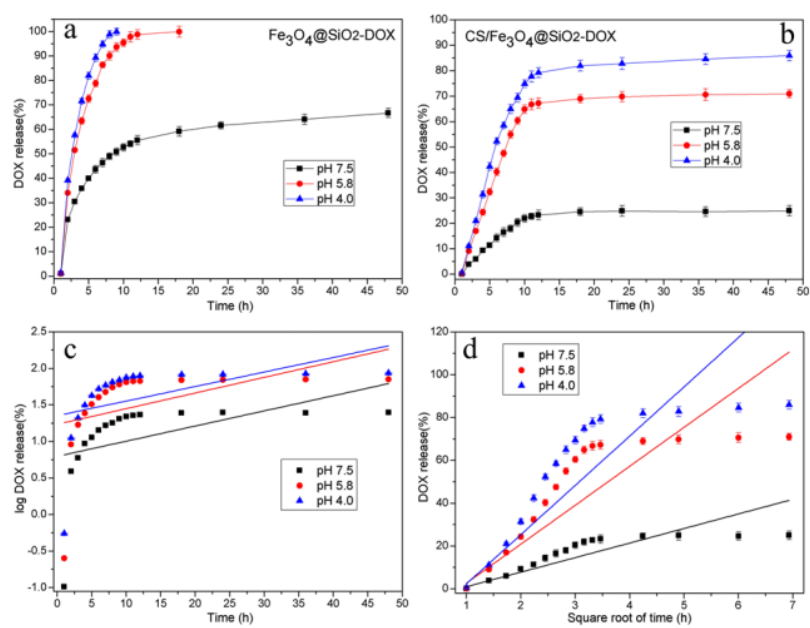


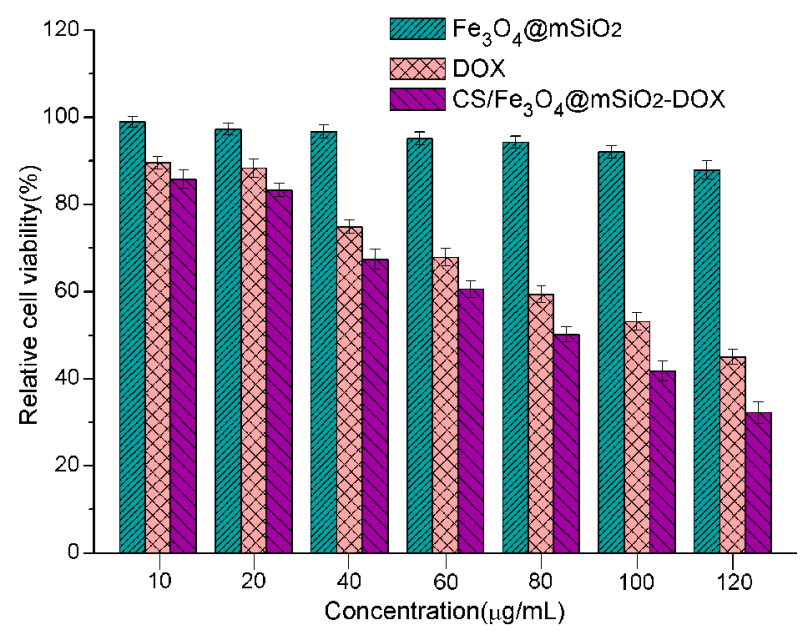




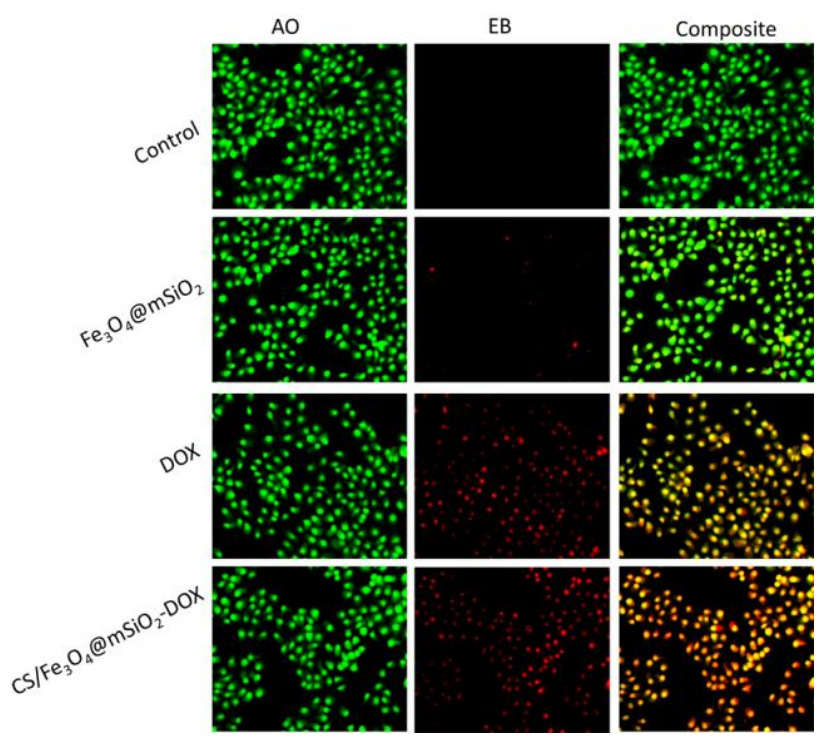




\section{Synthesis and characterization of mesoporous magnetic}

\section{nanocomposites wrapped with chitosan gatekeepers for $\mathrm{pH}$-sensitive}

\section{controlled release of doxorubicin}

Juan Wu, Wei Jiang, Yewen Shen, Wei Jiang ${ }^{*}$, Renbing Tian

National Special Superfine Powder Engineering Research Center, Nanjing University of Science and Technology, Nanjing 210094, China

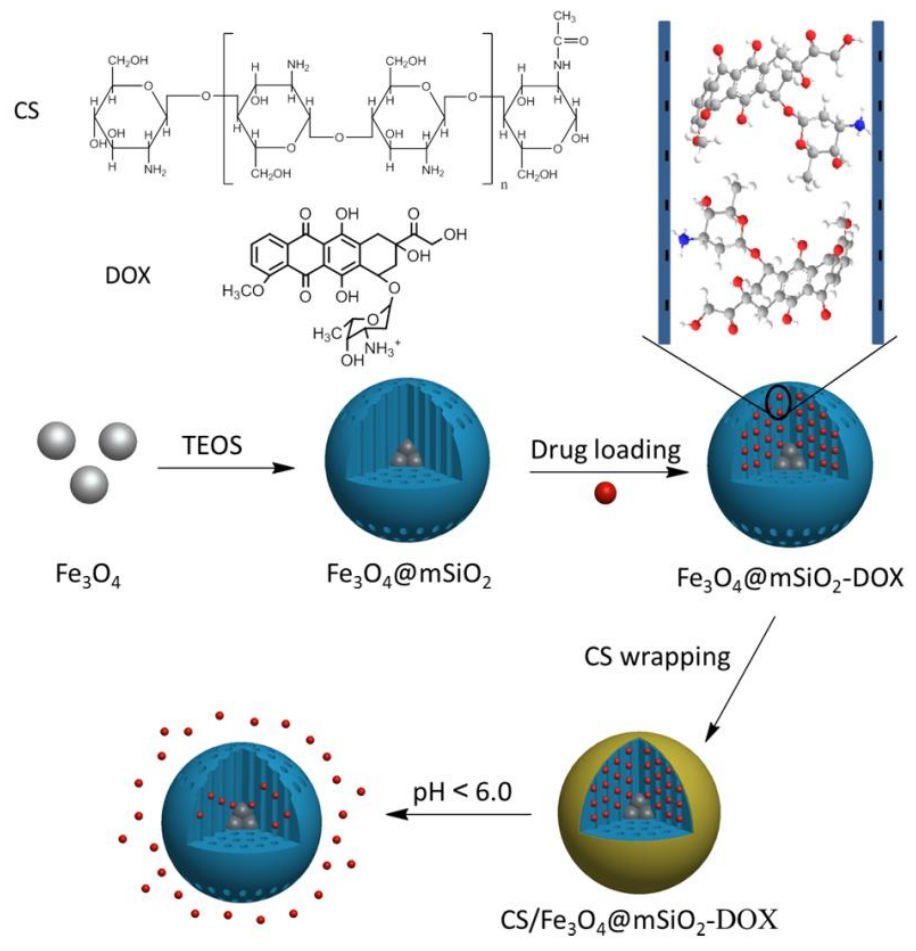

${ }^{*}$ Corresponding author. Tel.: +86-25-84315042; Fax.: +86-25-84315042

E-mail address: superfine_jw@126.com (W. Jiang) 